\title{
Proteolytic Processing of the Cyt1Ab1 Toxin Produced by Bacillus thuringiensis subsp. medellin
}

\author{
Elizabeth Escobar, Cesar Segura, Magnolia Vanegas*, Manuel E Patarroyo*, \\ Sergio Orduz ${ }^{+}$
}

Unidad de Biotecnología y Control Biológico, Corporación para Investigaciones Biológicas, Apartado Aéreo 7378, Medellín, Colombia *Instituto de Inmunología, Hospital San Juan de Dios, Santafé de Bogotá, Colombia

Bacillus thuringiensis produces $\delta$-endotoxins that require proteolytic processing to become active. The activation of the $B$. thuringiensis subsp. medellin $28 \mathrm{kDa}$ (Cyt1Ab1) cytolytic toxin by trypsin, chymotrypsin and gut extract from Culex quinquefasciatus larvae was analyzed. The Cyt1Ab1 toxin of B. thuringiensis subsp. medellin was processed by all proteases tested to fragments between 23 and 25 $\mathrm{kDa}$, while processing of the Cyt1 Aa1 toxin produce fragments between 22.5 and $24.5 \mathrm{kDa}$. The Cyt $1 \mathrm{Ab} 1$ toxin was preferentially processed at the alkaline $\mathrm{pH}$ of 12 . The in vitro proteolytic processing of the Cyt1Ab1 toxin by $C$. quinquefasciatus larvae midgut extract showed a $25 \mathrm{kDa}$ fragment; a similar result was observed when the activation was performed in the in vivo experiments. The solubilized Cyt $1 \mathrm{Ab} 1$ toxin and the protease resistant cores generated by in vitro processing showed hemolytic activity but not mosquitocidal activity. Amino terminal sequence of the C. quinquefasciatus gut extract resistant fragment indicated that the cutting site was located between Lys ${ }^{31}$ and $\mathrm{Asp}^{32}$, with a sequence DDPNEKNNHNS; while for the trypsin-resistant fragment the cutting site was determined between $\mathrm{Leu}^{29}$ and $\mathrm{Arg}^{30}$, and for the chymotrypsin-resistant fragment between $\mathrm{Arg}^{30}$ and $\mathrm{Lys}^{31}$.

Key words: Bacillus thuringiensis - Cyt1Ab1- cytolytic - hemolytic - proteolytic processing - midgut proteases

The Bacillus thuringiensis parasporal inclusions are composed of polypeptides, grouped in two types Cry and Cyt toxins (Crickmore et al. 1998, Schnepf et al. 1998). The Cry type of proteins are toxic to different orders of insect such as Lepidoptera, Diptera and Coleoptera. The Cyt proteins with molecular weight between 25 and $30 \mathrm{kDa}$ display cytolytic and mosquitocidal activity (Chilcott \& Ellar 1988, Koni \& Ellar 1994, Orduz et al. 1996); however, the mosquitocidal activity is lower than the Cry toxins (Chang et al. 1993, Crickmore et al. 1995, Orduz et al. 1996).

Several reports have demonstrated the in vivo and in vitro activation of the Cry-type of toxins (Carroll \& Ellar 1989, Pfannenstiel et al. 1990, Ogiwara et al. 1992, van Frankenhuyzen et al. 1993, Dai \& Gill 1993), and the Cyt-type of toxins (Al-yahyaee \& Ellar 1995, Li et al. 1996), and some

\footnotetext{
This work received financial support from Colciencias, Instituto de Inmunología and Corporación para Investigaciones Biológicas.

${ }^{+}$Corresponding author Fax: +574-441.5514. E-mail: sorduz@epm.net.co

Received 28 September 1999

Accepted 22 March 2000
}

of them when activated by proteases showed an enhanced cytolytic and larvicidal activity (Chilcott \& Ellar 1988, Knowles et al. 1992, Koni \& Ellar 1994).

B. thuringiensis subsp. medellin is a mosquitocidal strain described by Orduz et al. (1992). Its parasporal inclusion contains three main proteins of $94 \mathrm{kDa}(\mathrm{Cry} 11 \mathrm{Bb} 1), 68 \mathrm{kDa}$, and a 28 kDa (Cyt1Ab1) (Orduz et al. 1994, 1998, Thiéry et al. 1997). It has been suggested that Cyt toxins act sinergistically with the Cry toxins to produce mosquitocidal activity (Chang et al. 1993, Crickmore et al. 1995). The protein Cyt1Ab1 of $28 \mathrm{kDa}$ produced by $B$. thuringiensis subsp. medellin acts synergically with the $68 \mathrm{kDa}$ (Orduz et al. 1996), and the Cyt1Ab1 toxin shares $86 \%$ aminoacid identity with the toxin Cyt1Aa1 of $B$. thuringiensis subsp. israelensis. The cytlAbl gene encodes a polypeptide of 251 amino acids with a predicted molecular mass of $27.5 \mathrm{kDa}$ (Thiéry et al. 1997). It has been demonstrated that the Cyt1Aa1 protein is also toxic to coleopteran insects, and that it can reduce the resistance ratio of Chrysomela scripta to the Cry3Aa toxin (Federici \& Bauer 1998). At the same time, Thiery et al. (1998) demonstrated that the Cyt1Ab1 protein can also reduce the resistance of Culex quinquefasciatus to the binary toxin of $B$. sphaericus.

In this work, we evaluated the in vitro activity of standard and midgut proteases on the Cyt1Ab1 
toxin and analyzed the resulting products. We also studied the effect of the $\mathrm{pH}$ on the in vitro proteolysis of the Cyt1 $\mathrm{Ab} 1$ protein, determined the in vivo processing of the toxin, and assayed the hemolytic and mosquitocidal activity of the in vitro processed Cyt1 Ab1 protein.

\section{MATERIALS AND METHODS}

Bacterial strains, mosquitoes, antibodies and proteases - The Cyt1Ab1 toxin was obtained from a recombinant strain SPL407, a crystal negative strain of $B$. thuringiensis subsp. thuringiensis carrying the cytlAbl gene cloned from $B$. thuringiensis subsp. medellin (Thiéry et al. 1997). The $B$. thuringiensis recombinant strain carrying the plasmid pWF45 encoding the Cyt1Aal protein, was kindly provided by Dr Brian A Federici, University of California. The bacteria were grown in Luria-Bertani (LB) liquid medium or on LB agar plates (Sambrook et al. 1989) supplemented with erythromycin $(25 \mu \mathrm{g} / \mathrm{ml})$. C. quinquefasciatus were maintained under laboratory conditions $\left(30^{\circ} \mathrm{C} \pm 2^{\circ} \mathrm{C}\right.$ and a 12:12 light:dark photoperiod). Antibodies anti-Cyt1Ab1 were raised in mice according to Sambrook et al. (1989). Trypsin and chymotrypsin were purchased from Sigma Chemical Co. (St. Louis, Mo).

Gut extract preparation - The gut extract was prepared from third instar $C$. quinquefasciatus larvae according to Garczynski et al. (1991) with modifications. Mosquito larvae were chilled on ice for $30 \mathrm{~min}$. The guts were excised and collected in MET buffer (Mannitol $300 \mathrm{mM}$, EDTA $5 \mathrm{mM}$, Tris $20 \mathrm{mM}, \mathrm{pH}$ 7.2). Then, they were disrupted and centrifuged. The supernatant with protease activity was recovered and the protein content was determined by Bradford microassay protocol (BioRad, Hercules, CA, USA), using bovine serum albumin (BSA) as standard.

Crystal purification - Recombinant strains containing the cytlAal and cytlAbl genes were incubated in $5 \mathrm{ml}$ of M-one liquid medium (Restrepo et al. 1997) supplemented with erythromycin $(25 \mu \mathrm{g} / \mathrm{ml})$, for $12 \mathrm{~h}$ at $30^{\circ} \mathrm{C}$ and $200 \mathrm{rpm}$. Cultures were transferred to $200 \mathrm{ml}$ of M-one liquid medium and incubated for $120 \mathrm{~h}$ at $30^{\circ} \mathrm{C}$ and 200 rpm until sporulation. The presence of crystals and spores was checked by light microscopy. The medium was removed by centrifugation at $9,000 \mathrm{rpm}$, at $4^{\circ} \mathrm{C}$ for $15 \mathrm{~min}$, the pellet (crystal-spore complex) was resuspended in $1 / 20$ th of the original volume in $1 \mathrm{M} \mathrm{NaCl}$ and shaken for $2 \mathrm{~h}$, at $37^{\circ} \mathrm{C}$ and $150 \mathrm{rpm}$ to neutralize protease activity, and then washed twice in ice-cold distilled water supplemented with $1 \mathrm{mM}$ phenyl-methyl-sulfonylfluoride (PMSF) and $10 \mathrm{mM}$ EDTA (Thiéry et al. 1997). Crystals were separated on a discontinuous sucrose gradient 67-79\% (w/v) (Thiéry et al. 1998) at $25,000 \mathrm{rpm}$ for $2 \mathrm{~h}$ at $4^{\circ} \mathrm{C}$. The pure crystals were collected, washed four times with sterile icecold distilled water and concentrated by centrifugation at $4^{\circ} \mathrm{C}, 12,000 \mathrm{rpm}$ during $10 \mathrm{~min}$. Finally, the crystals were resuspended in $2 \mathrm{ml}$ of sterile water, aliquoted, and stored at $-20^{\circ} \mathrm{C}$ until use. The purity of crystals was determined by light-microscopy and the crystal composition was checked by sodium dodecyl sulfate-polyacrylamide gel electrophoresis (SDS-PAGE) and proteins were stained with Coomasie brilliant blue.

Solubilization of the Cyt1Ab1 crystals - The solubilization of Cyt1 Ab1 crystals was performed at different $\mathrm{pH}$ with the buffer system listed in Table I. For the solubilization assay, $10 \mu$ of crystals were incubated with $15 \mu \mathrm{l}$ of each buffer at $37^{\circ} \mathrm{C}, 200 \mathrm{rpm}$ during $2 \mathrm{~h}$. Unsoluble material was removed by centrifugation at $12,000 \mathrm{rpm}$ and soluble protein concentration was measured by Bradford as above.

In vitro proteolytic processing of the Cyt $1 \mathrm{Abl}$ toxin - The Cyt1 Ab1 toxin was treated with trypsin (10 units per mg of protein), chymotrypsin (40-60 units per $\mathrm{mg}$ of protein) and $C$. quinquefasciatus gut extracts in a 1:10 ratio (w/w, enzyme/ toxin) in a final volume of $10 \mu \mathrm{l}$ and incubated at $30^{\circ} \mathrm{C}$ for $14 \mathrm{~h}$ in buffers of different $\mathrm{pH}$. The resulting digests were examined by SDS-PAGE $10 \%$, stained with Coomasie brilliant blue and analyzed by the NIH program v. 1.61 (Seebacher \& Bade 1996).

The processing of the Cyt1Ab1 toxin in time was studied with trypsin, chymotrypsin and mosquito larvae gut extracts in a 1:2.5 ratio (w/w enzyme/toxin) using carbonate buffer $\mathrm{pH} 11$. Ten microliters of each reaction were collected at different times $(1,5,10,30 \mathrm{~min}, 1,2,3,14$, and 24 h), and mixed with $15 \mu \mathrm{l}$ of Laemmli buffer, $3 \mu \mathrm{l}$ of PMSF $100 \mathrm{mM}$, and $3 \mu \mathrm{l}$ EDTA $100 \mathrm{mM}$ (pH 8.5). Samples were boiled for $5 \mathrm{~min}$, and then subjected to SDS-PAGE 10\%. Gels were stained with Coomasie brilliant blue and analyzed as above.

To compare the in vitro proteolytic processing of Cyt1Ab1 and Cyt1Aa1 crystals, both toxins were treated with trypsin, chymotrypsin and $C$. quinquefasciatus gut extract larvae in a 1:2.5 ratio (w/w enzyme/toxin) using carbonate buffer $\mathrm{pH} 11$ during $24 \mathrm{~h}$, subjected to SDS-PAGE $10 \%$ and analyzed as above.

In vivo proteolysis assays of the CytlAb1 crystals - These assays were conducted in microplates containing five $C$. quinquefasciatus third instar larvae in each well and $1 \mathrm{ml}$ of distilled water. Three different Cyt1Ab1 crystal concentrations were tested $(25 \mu \mathrm{g} / \mathrm{ml}, 12.5 \mu \mathrm{g} / \mathrm{ml}$ and $6 \mu \mathrm{g} / \mathrm{ml})$, and bioassays were incubated at room temperature 
$\left(26 \pm 2^{\circ} \mathrm{C}\right)$ until the first signs of larval intoxication were observed ( 1 to $2 \mathrm{~h}$ later). Larval guts were dissected and collected in a tube containing $15 \mu \mathrm{l}$ of Laemmli buffer, $3 \mu \mathrm{l}$ of PMSF $100 \mathrm{mM}$, and 3 $\mu$ EDTA $100 \mathrm{mM}$ (pH 8.5). Samples were boiled for $5 \mathrm{~min}$ and subjected to SDS-PAGE 10\%. Proteins were electro-transferred to nitrocellulose membranes at a constant current of $26 \mathrm{~mA}$ for $2 \mathrm{~h}$. Non-specific binding sites were blocked with 3\% gelatin in Tris buffer saline, TBS (Tris $20 \mathrm{mM}$, $\mathrm{NaCl} 500 \mathrm{mM}, \mathrm{pH}$ 7.5) for $1 \mathrm{~h}$, then washed three times with TTBS (TBS, $0.05 \%$ Tween 20). Subsequently, the membrane was incubated with polyclonal anti-Cyt1Ab1 antibody (1:1000 working dilution) in $1 \%$ gelatin in TTBS for $1 \mathrm{~h}$ and washed three times in TTBS. Goat anti-mouse IgG $(\mathrm{H}+\mathrm{L})$-alkaline phosphatase conjugate $(1: 1000$ working dilution) was used as secondary antibody and incubated for $1 \mathrm{~h}$, and then washed with TTBS. Color was developed by using a chromogenic reaction with nitroblue tetrazolium chloride $(1 \mathrm{mg} /$ $\mathrm{ml})$ and 5-bromo-4-cloro-3-indolyl-phosphate (5 $\mathrm{mg} / \mathrm{ml}$ ) in carbonate buffer $\mathrm{pH} 9.85$.

Identification of protease cleavage sites - The in vitro-processed Cyt $1 \mathrm{Ab}$ toxin with trypsin chymotrypsin and $C$. quinquefasciatus gut extracts were separated by SDS-PAGE and transferred to PVDF membrane as described by Mozdzanowski and Speicher (1992). Individual bands were excised with a sterile blade and applied to a sample cartridge of an automated sequencer (Applied Biosystems model 477A). The analysis of aminoacid-phenylthiohydantoin derivatives was performed on line using an HPLC system (Applied Biosystems model 120A).

In vitro hemolysis assays - This assay was carried out as described by Thiéry et al. (1997) with a few modifications. Five $\mathrm{ml}$ of sheep blood were washed twice in $15 \mathrm{mM}$ Tris- $\mathrm{HCl} 0.17 \mathrm{M} \mathrm{NaCl}$, $\mathrm{pH} 8.0$ and resuspended to a final concentration of $4.5 \%$ in the same buffer. The Cyt1Ab1 toxin was solubilized in $\mathrm{NaOH} 50 \mathrm{mM}$, EDTA $10 \mathrm{mM}$ (pH
12) during $45 \mathrm{~min}$ at $37^{\circ} \mathrm{C}$, and treated with trypsin, chymotrypsin and gut extracts from $C$. quinquefasciatus larvae as above. Five hundred $\mu \mathrm{l}$ of each concentration of the soluble and protease treated toxin were added to $500 \mu \mathrm{l}$ of the erythrocyte suspension. Each treatment was carefully mixed and incubated at $37^{\circ} \mathrm{C}$ for $45 \mathrm{~min}$ and then centrifuged at 12,000 rpm for $2 \mathrm{~min}$. The amount of hemoglobin released was estimated in a spectrophotometer at $535 \mathrm{~nm}$. The half hemolytic dose $\left(\mathrm{HD}_{50}\right)$ defined as the amount of toxin needed to release half the hemoglobin from the erythrocytes was calculated by probit analysis using a computer program (Raymond 1995). Each assay was performed by triplicate in three different days.

Mosquitocidal activity assay - The toxicity of ten dilutions of crystals, solubilized and activated Cyt1Ab1 toxin were tested against $C$. quinquefasciatus first instar larvae in 24 well plates. Five mosquito larvae were set by well in $1 \mathrm{ml}$ of sterile distilled water according to Orduz et al. (1996). Each toxin concentration was tested by duplicate, and bioassays were conducted in three different days. Larval mortality was scored $24 \mathrm{~h}$ later, the half lethal concentration $\left(\mathrm{LC}_{50}\right)$ was calculated as above.

\section{RESULTS}

Solubilization of Cyt1Ab1 parasporal inclusions - Solubilization of the Cyt1 Ab1 crystals was directly proportional to the increase in $\mathrm{pH}$. In general, the Cyt1Ab1 toxin was preferentially solubilized in higher amounts in buffers of basic $\mathrm{pH}$. The acidic buffers (pH 5.0 and 6.0) and neutral buffers (pH 7.0) showed the lowest solubilization. In the basic buffers ( $\mathrm{pH} 8.0$ to 10.0), a gradual increase of soluble toxin was observed, obtaining the higher toxin concentration in the buffers with $\mathrm{pH}$ values between 10.6, and 12.0, with a maximal toxin concentration obtained of $2.33 \mu \mathrm{g} / \mathrm{ml}$ (Table I).

Effect of $\mathrm{pH}$ on the proteolytic processing of CytlAbl crystals - The proteolytic activity of the

TABLE I

Solubilization of Bacillus thuringiensis subsp. medellin Cyt1Ab1 toxin in buffers of different $\mathrm{pH}$

\begin{tabular}{|c|c|c|}
\hline Buffer & $\mathrm{pH}$ & $\begin{array}{l}\text { Concentration of solubilized } \\
\text { Cyt1 } \mathrm{Ab} 1 \text { toxin }(\mu \mathrm{g} / \mathrm{ml})\end{array}$ \\
\hline $\mathrm{Na}_{2} \mathrm{HPO}_{4} 50 \mathrm{mM}, \mathrm{KH}_{2} \mathrm{PO}_{4} 50 \mathrm{mM}$ & 5.0 & 0.3 \\
\hline $\mathrm{Na}_{2} \mathrm{HPO}_{4} 50 \mathrm{mM}, \mathrm{KH}_{2} \mathrm{PO}_{4} 50 \mathrm{mM}$ & 6.0 & 0.3 \\
\hline $\mathrm{Na}_{2} \mathrm{HPO}_{4} 50 \mathrm{mM}, \mathrm{KH}_{2} \mathrm{PO}_{4} 50 \mathrm{mM}$ & 7.0 & 0.3 \\
\hline Tris $\mathrm{HCl}^{4} 50 \mathrm{mM}$ & 8.0 & 0.4 \\
\hline $\mathrm{Na}_{2} \mathrm{CO}_{3} 50 \mathrm{mM}, \mathrm{NaHCO}_{3} 50 \mathrm{mM}$ & 9.0 & 0.5 \\
\hline $\mathrm{Na}_{2} \mathrm{CO}_{3} 50 \mathrm{mM}, \mathrm{NaHCO}_{3} 50 \mathrm{mM}$ & 10.0 & 0.7 \\
\hline $\mathrm{Na}_{2} \mathrm{CO}_{3} 50 \mathrm{mM}, \mathrm{NaHCO}_{3} 50 \mathrm{mM}$ & 10.6 & 1.2 \\
\hline $\mathrm{Na}_{2} \mathrm{CO}_{3} 50 \mathrm{mM}, \mathrm{NaHCO}_{3} 50 \mathrm{mM}$ & 11.0 & 1.5 \\
\hline $\mathrm{NaOH} 50 \mathrm{mM}$, EDTA $10 \mathrm{mM}$ & 12.0 & 2.3 \\
\hline
\end{tabular}


C. quinquefasciatus gut extract was only observed in the alkaline buffers after $14 \mathrm{~h}$ of incubation $(\mathrm{pH}$ 10.6 and above). In the buffers of $\mathrm{pH} 10.6$ and 11, the proteolytic product of the Cyt1Ab1 was seen as a weak band and the complete proteolysis was indicated by the formation of a $25 \mathrm{kDa}$ fragment, observed at the $\mathrm{pH}$ of 12 (Fig. 1A, lane 11). The activation of the Cyt1Ab1 toxin with trypsin and chymotrypsin was slightly different at the same $\mathrm{pH}$ conditions and produced fragments of $26 \mathrm{kDa}$ and $25 \mathrm{kDa}$, respectively (Figs 1B, 1C, lanes 11).

Kinetics of the CytlAb1 proteolysis - The appearance of intermediaries and protease resistant fragments of the Cyt1Ab1 toxin was observed at different time intervals after treatment with proteases. The action of $C$. quinquefasciatus gut extract in the processing of Cyt1 Ab1 was observed 1 min after treatment, being most evident 10 min later. Between 3 and $14 \mathrm{~h}$, the Cyt1Ab1 toxin was converted to a $25 \mathrm{kDa}$ fragment (Fig. 2A). Proteolysis with trypsin did not generate intermediaries and produced a $26 \mathrm{kDa}$ fragment $14 \mathrm{~h}$ after treatment (Fig. 2B, lane 10). Processing of the Cyt1 Ab1 toxin with chymotrypsin clearly showed the generation of 25 and $26 \mathrm{kDa}$ fragments as early as $1 \mathrm{~min}$ after the proteolysis had started, and generated a $24.5 \mathrm{kDa}$ protease resistant core $21 \mathrm{~h}$ later (Fig. 2C, lane 11).

Comparative proteolytic processing - In vitro processing of Cyt1Ab1 and Cyt1Aa1 toxins with proteases showed slight differences in the size of the generated fragments. After $24 \mathrm{~h}$ of treatment with $C$. quinquefasciatus gut extract, $\mathrm{Cyt} 1 \mathrm{Ab} 1$ and Cyt1Aa1 generated fragments of 23 and $22.5 \mathrm{kDa}$, respectively (Fig. 3, lanes 4, 5); treatment with trypsin generated fragments of 25 and $24 \mathrm{kDa}$ (Fig. 3 , lanes 6,7$)$, and treatment with chymotrypsin produced fragments of 25 and $24.5 \mathrm{kDa}$, respectively (Fig. 3, lanes 8, 9).

In vivo proteolysis of Cyt1Abl inclusion - The processing of the parasporal inclusion containing

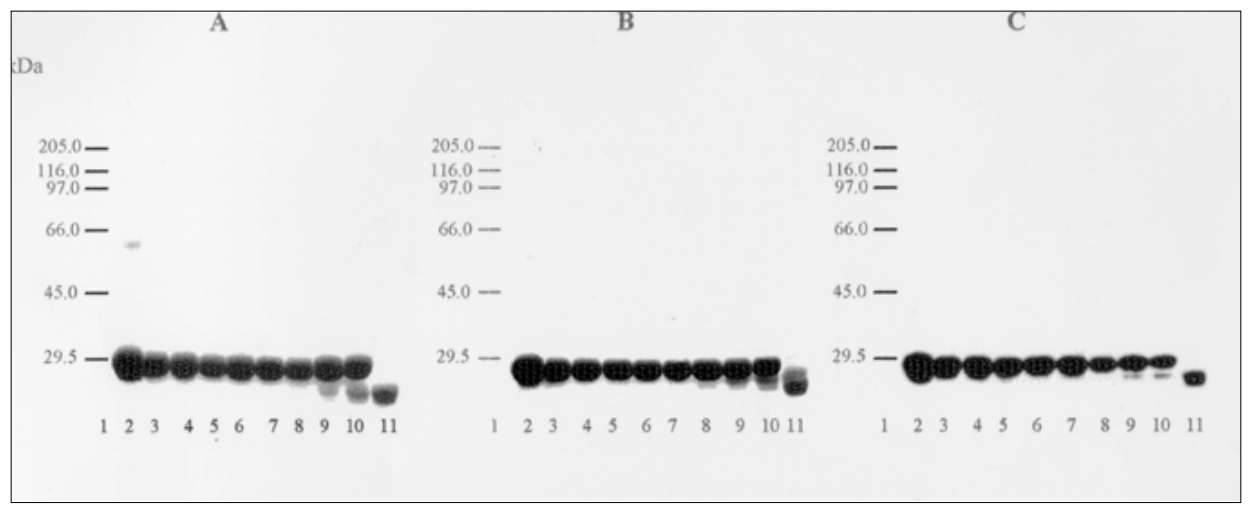

Fig. 1: effect of $\mathrm{pH}$ on the proteolysis of the Cyt1 Ab1 crystal inclusions. A: proteolysis by Culex quinquefasciatus gut extract; B: proteolysis by trypsin; C: proteolyis by chymotrypsin. Lanes 1: molecular weight marker; lanes 2: Cyt1 Ab1 crystal inclusion; lanes 3: proteolysis of soluble Cyt1 Ab1 toxin at $\mathrm{pH}$ 5; lanes 4: at $\mathrm{pH}$ 6; lanes 5: at $\mathrm{pH} 7$; lanes 6: at $\mathrm{pH}$ 8; lanes 7: at $\mathrm{pH} 9$; lanes 8: at $\mathrm{pH}$ 10; lanes 9: at $\mathrm{pH}$ 10.6; lanes 10: at $\mathrm{pH}$ 11; lanes 11: at $\mathrm{pH} 12$

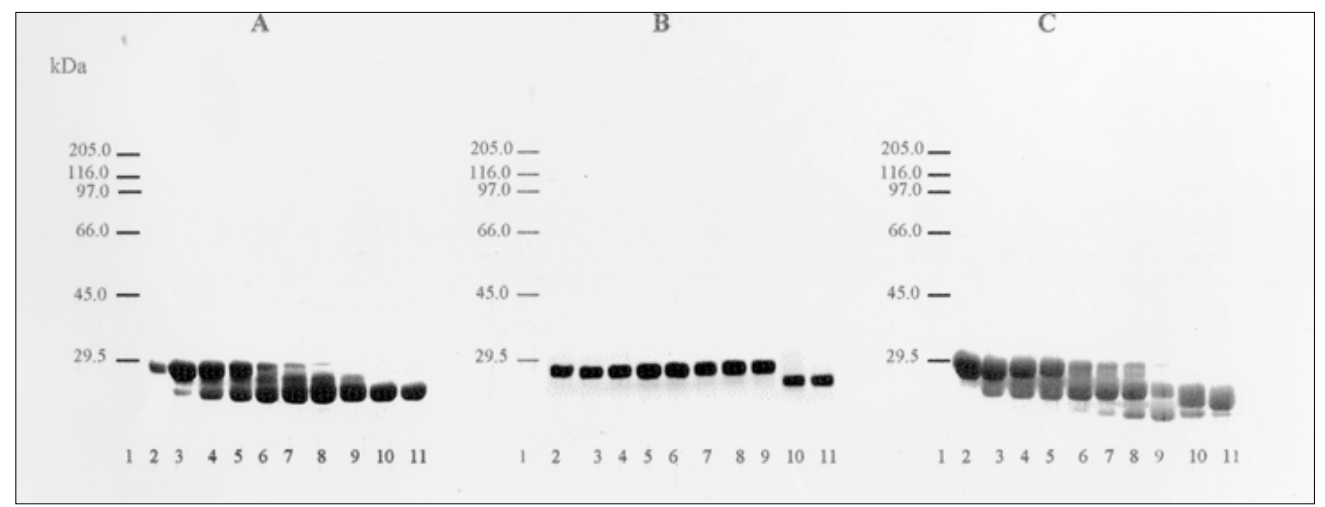

Fig. 2: time course processing of Cyt1Ab1 toxin with different proteases. A: proteolysis by Culex quinquefasciatus gut extract; B: proteolysis by trypsin; C: proteolysis by chymotrypsin. Lanes 1: molecular weight marker; lanes 2: Cyt1Ab1 crystal inclusion; lanes 3: after $1 \mathrm{~min}$; lanes 4: after $5 \mathrm{~min}$; lanes 5: after $10 \mathrm{~min}$; lanes 6: after $30 \mathrm{~min}$; lanes 7: after 1h, lanes 8: after 2h; lanes 9: after $3 \mathrm{~h}$; lanes 10: after $12 \mathrm{~h}$; lanes 11: after $21 \mathrm{~h}$ 
the Cyt1Ab1 toxin by third instar C. quinquefasciatus larvae was analyzed at different concentrations of the toxin $(25 \mu \mathrm{g}, 12.5 \mu \mathrm{g}$ and $6 \mu \mathrm{g}$ of toxin inclusions, and soluble toxin at $25 \mu \mathrm{g} / \mathrm{ml}$ ). In vivo processing of the crystals generated a weak $25 \mathrm{kDa}$ fragments, similar in size to those observed during the in vitro proteolysis (compare in Fig. 4, lanes 3-5 to lane 7).

In vitro hemolysis on sheep red blood cells with soluble and processed Cyt1Abl toxin - The alkalisolubilized Cyt1 Ab1 toxin showed an $\mathrm{HD}_{50}$ of 4.5 $\mu \mathrm{g} / \mathrm{ml}$ in sheep red blood cells (Table II) and 3.6 $\mu \mathrm{g} / \mathrm{ml}$ for human erythrocytes (data not shown). Cyt1Ab1 toxin processed in vitro with mosquito

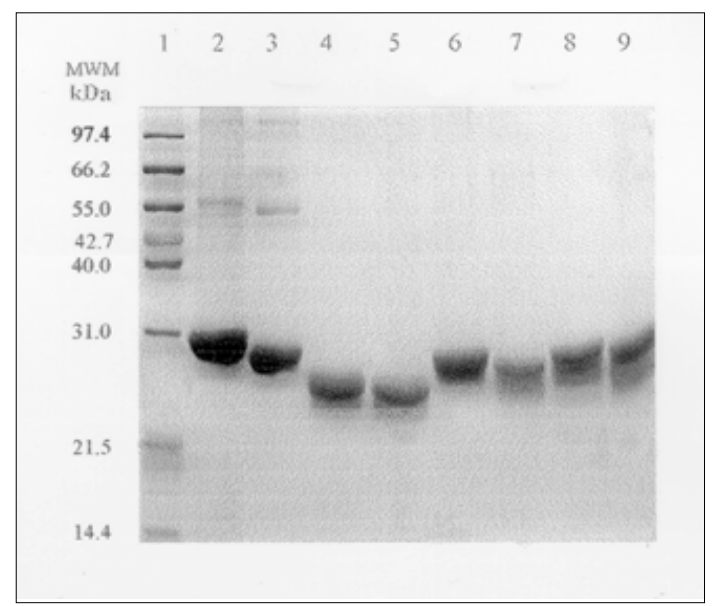

Fig. 3: comparative analysis of the in vitro proteolytic processing of the Cyt1 Ab1 toxin of Bacillus thuringiensis subsp. medelin and Cyt1Aa1 toxin of B. thuringiensis subsp. israelensis with different proteases. Lane 1: molecular weight marker; lane 2: Cyt1Ab1; lane 3: Cyt1Aa1; lanes 4 and 5: Cyt1Ab1 and Cyt1Aa1 processed by Culex quinquefasciatus gut extract; lanes 6 and 7: Cyt1Ab1 and Cyt1Aa1 processed by trypsin; lanes 8 and 9: Cyt1Ab1 and Cyt1Aa1 processed by chymotrypsin. larvae gut extract, trypsin and chymotrypsin showed similar $\mathrm{HD}_{50}$, and this hemolytic activity was higher than the activity of the solubilized toxin (Table II).

Mosquitocidal activity assay - The mosquitocidal activity of the Cyt1Ab1 crystal inclusions against third instar C. quinquefasciatus larvae showed an $\mathrm{LC}_{50}$ of $1.3 \mu \mathrm{g} / \mathrm{ml}$ for Cyt $1 \mathrm{Ab} 1$ toxin and $0.74 \mu \mathrm{g} / \mathrm{ml}$ for Cyt1Aa1 toxin. Even though we used $25 \mu \mathrm{g} / \mathrm{ml}$ of soluble Cyt1Ab1 toxin, or processed toxin by trypsin, chymotrypsin and C. quinquefasciatus gut extract, no toxicity could be detected in the bioassays (Table II).

Identification of protease cleavage sites - Protease-resistant fragments separated by SDS-PAGE

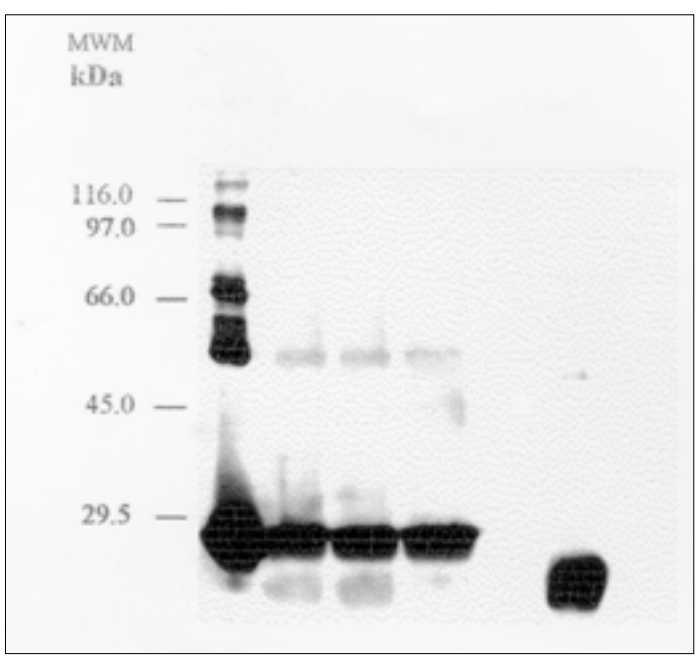

Fig. 4: in vitro processing of the Cyt $1 \mathrm{Ab} 1$ soluble toxin by third instar Culex quinquefasciatus larvae. Larvae were incubated with $25 \mu \mathrm{g}$ (lane 6) of soluble toxin. Lane 1: molecular weight markers; lane 2: Cyt1Ab1 toxin inclusions; lane 7: 10 $\mu \mathrm{g}$ of Cyt1 Ab1 toxin in vitro digested with C. quinquefasciatus gut extract; lane 8: C. quinquefasciatus guts.

\section{TABLE II}

Mosquitocidal and hemolytic activities of inclusions, solubilized and proteolytically processed Cyt1Ab1 toxin of Bacillus thuringiensis subsp. medellin against Culex quinquefasciatus third instar larvae and sheep red blood cells

\begin{tabular}{lll}
\hline Toxin & $\begin{array}{l}\text { Half lethal concentration } \\
\mathrm{LC}_{50}(\mu \mathrm{g} / \mathrm{ml})\end{array}$ & $\begin{array}{l}\text { Half hemolytic concentration } \\
\mathrm{HD}_{50}(\mu \mathrm{g} / \mathrm{ml})\end{array}$ \\
\hline Cyt1Aa1 crystals & $0.74(0.5-0.9)^{a}$ & $\mathrm{ND}$ \\
Cyt1Ab1 crystals & $1.3(0.9-1.7)$ & $\mathrm{NH}$ \\
Cyt1Ab1 solubilized & $\mathrm{NT}$ & $4.5(3.4-6.1)$ \\
Cyt1Ab1 activated by & $\mathrm{NT}$ & $1.4(0.4-2.0)$ \\
C. quinquefasciatus gut extracts & & \\
Cyt1Ab1 activated by trypsin & $\mathrm{NT}$ & $2.2(1.6-3.3)$ \\
Cyt1Ab1 activated by chymotrypsin & $\mathrm{NT}$ & $1.9(1.5-2.6)$ \\
\hline
\end{tabular}

$a$ : values in parenthesis represent the $95 \%$ confidence limits, determined by Probit analysis, ND: not determined; NH: not hemolytic; NT: not toxic 
were transferred to PVDF membranes. Eleven aminoacids from the $\mathrm{N}$-terminal part were sequenced and compared to the deduced aminoacid sequence (Thiery et al. 1997). The N-terminal sequence of the fragment generated by treatment with C. quinquefasciatus gut extract corresponded to DDPNEKNNHNS, with the cutting site located between residues Ile ${ }^{31}$ and $\mathrm{Asp}^{32}$ (Table III). The cutting site generated by trypsin was Leu ${ }^{29}$ and $\mathrm{Arg}^{30}$ and for chymotrypsin $\mathrm{Arg}^{30}$-Lys $^{31}$ indicating a shift of one and two aminoacids compared to the protease-resistant fragment generated by treatment of the Cyt1Ab1 toxin with mosquito larvae gut extract.

\section{DISCUSSION}

The midgut of mosquito larvae has an alkaline $\mathrm{pH}$ (Dadd 1975) and contains trypsin, chymotrypsin (Yang \& Davies 1971, Kunz 1978) and thermolysin-like proteases which are active at this pH (Dai \& Gill 1993). It is accepted that the $B$. thuringiensis crystals are solubilized in the alkaline environment of the insect midgut, and then cleaved by midgut proteases to produce the toxic fragments (Tojo \& Aizawa 1983, Aronson et al. 1986). Dai and Gill (1993) showed that the Cry11Aa1 toxin of $B$. thuringiensis subsp. israelensis is processed to fragments of 30 and $28.5 \mathrm{kDa}$ by trypsin and chymotrypsin-like proteases, and to a $28 \mathrm{kDa}$ fragment by thermolysin-like proteases present in C. quinquefasciatus larval midguts.

The recombinant Cyt1 Ab1 toxin was poorly solubilized in buffers with $\mathrm{pH}$ ranging from 5 to 10 ; while toxin solubilization superior to 1 $\mu \mathrm{g} / \mu \mathrm{l}$ was only obtained in buffers of $\mathrm{pH} 10.6$ and above (Table I). Reduced protease activity on the Cyt1Ab1 protein was observed in buffers of $\mathrm{pH}$ bellow 11 (Figs 1A, B, C), while fully processed Cyt1 $\mathrm{Ab} 1$ toxin was only observed in the buffer of pH 12 (lanes 11, in Figs 1A, 1B,
1C). A clear dependence between Cyt1Ab1 crystal protein solubilization, $\mathrm{pH}$, and proteolytic activity was observed, results that agree with the observations of Fast and Milne (1979) and Dai and Gill (1993), who showed that the $\mathrm{pH}$ is an important factor for $B$. thuringiensis crystal solubilization and that an alkaline $\mathrm{pH}$ is required for efficient toxin proteolytic activity on mosquito larvae midguts.

The proteolytical activity over the Cyt toxins has been described (Chilcott \& Ellar 1988, Knowles et al. 1992, Koni \& Ellar 1994, Alyahyaee \& Ellar 1995). The time course study of the Cyt1Ab1 proteolysis revealed that treatments with chymotrypsin and $C$. quinquefasciatus gut extract produced a $25 \mathrm{kDa}$ fragment, and the proteolytic activity of trypsin generated a $26 \mathrm{kDa}$ fragment. It is possible that activity similar to trypsin and chymotrypsin could be present in $C$. quinquefasciatus gut extract, and probably other proteases could participate in this process, as has been demonstrated previously for the activation of the Cry11Aa toxin (Dai \& Gill 1993).

Longer incubation time ( $24 \mathrm{~h}$ ) of the Cyt1Ab1 toxin with $C$. quinquefasciatus gut extract produced a fragment of $23 \mathrm{kDa}$ (Fig. 3, lane 4); while the treatment with chymotrypsin generated a $25 \mathrm{kDa}$ fragment (Fig. 3, lane 8), similar in size to the one observed after $21 \mathrm{~h}$ of treatment.

The treatment of the Cyt1Aa1 toxin with trypsin generated a $23.5 \mathrm{kDa}$ fragment (Al-yahyaee \& Ellar 1995), while treatment of the Cyt1Ab1 toxin with the same protease generated a $26 \mathrm{kDa}$ fragment 21 after treatment (Fig. 2B, lane 11), and $3 \mathrm{~h}$ later, a $25 \mathrm{kDa}$ fragment was observed (Fig. 3, lane 6). Although Cyt1Aa1 and Cyt1Ab1 toxins share $86 \%$ of aminoacid identity (Thiéry et al. 1997), the difference in size of the enzyme digested fragments suggests that the toxins could have different protease susceptibility.

TABLE III

$\mathrm{N}$-terminal sequence of Cyt1Ab1 toxin of Bacillus thuringiensis subsp. medellin processed by different proteases

\begin{tabular}{|c|c|c|c|}
\hline Toxin & N-terminal sequence & Cutting site & Size \\
\hline & & & \\
\hline Cyt1Ab1 & Met-Glu-Asp-Pro-Asn-His-Cys-Pro-Leu & & 28 \\
\hline $\begin{array}{l}\text { Cyt1 Ab1 toxin processed by } \\
\text { Culex quinquefasciatus gut extract }\end{array}$ & Asp-Asp-Pro-Asn-Glu-Lys-Asn-Asn-Asn & $\mathrm{Ile}^{31}-\mathrm{Asp}^{32}$ & 23 \\
\hline $\begin{array}{l}\text { Cyt } 1 \mathrm{Ab} 1 \text { toxin processed by } \\
\text { trypsin }\end{array}$ & Arg-Lys-Asp-Asp-Pro-Asn-Glu-Lys-Asn & $\mathrm{Leu}^{29}-\mathrm{Arg}^{30}$ & 25 \\
\hline $\begin{array}{l}\text { Cyt1Ab1 toxin processed by } \\
\text { chymotrypsin }\end{array}$ & Lys-Asp-Asp-Pro-Asn-Glu-Lys-Asn-Asn & $\operatorname{Arg}^{30}$-Lys ${ }^{31}$ & 25 \\
\hline
\end{tabular}


The results of the in vitro processing of the Cyt1Ab1 toxin with $C$. quinquefasciatus gut extract were similar to the in vivo processing by third instar C. quinquefasciatus larvae. However the 25 $\mathrm{kDa}$ fragment generated by the in vivo experiments was seen as a weak band (Fig. 4, lanes 3-5), indicating that the proteolytic processing of the Cyt1Ab1 toxin was not very efficient and/or poor crystal protein solubilization took place, as shown in the solubilization experiments (Table I) and as previously described by Orduz et al. (1996). The bands seen in this experiment are different to the strong band observed when the Cyt1Ab1 toxin was treated with $C$. quinquefasciatus gut extract at $\mathrm{pH}$ 12 , a non physiological $\mathrm{pH}$ of the mosquito larvae midgut (Fig. 4, lane 7). It has been suggested that some Cry and Cyt toxins are active without prior proteolytic processing (Höfte \& Whiteley 1989, Knowles et al. 1992, Koni \& Ellar 1994). These observations could explain the larvicidal activity of Cyt1Ab1 crystal inclusions when they are ingested by $C$. quinquefasciatus larvae, despite the low processing within the larval gut (Fig. 4).

Thiéry et al. (1997) observed mortality in $C$. pipiens larvae treated with recombinant Cyt1 Ab1 crystal inclusions $\left(\mathrm{LC}_{50}\right.$ of $\left.5.7 \mu \mathrm{g} / \mathrm{ml}\right)$. Although we also observed mortality of $C$. quinquefascistus larvae challanged with recombinant Cyt1 Ab1 crystal inclusions $\left(\mathrm{LC}_{50} 1.3 \mu \mathrm{g} / \mathrm{ml}\right.$ ), no toxicity was observed when soluble and protease treated Cyt1Ab1 protein was used. Similar results were found by Schnell et al. (1984) where solubilized crystal proteins of $B$. thuringiensis subsp. israelensis were 7,000 times less active than crystals. Since Dadd (1975) demonstrated that mosquito larvae are mainly filter feeders, and do not ingest water or soluble compounds, it is possible that the mosquito larvae used in the bioassays with soluble and protease treated Cyt $1 \mathrm{Ab} 1$ toxin did not ingest an adequate amount of toxin to cause larval mortality (Table II).

Even though the solubilized and processed Cyt1Ab1 toxin was not mosquitocidal, hemolytic activity was detected and produced a half hemolytic concentration $\left(\mathrm{HD}_{50}\right)$ of $4.5 \mu \mathrm{g} / \mathrm{ml}$ in sheep erythrocytes (Table II). The $\mathrm{HD}_{50}$ of solubilized Cyt1Ab1 toxin was similar in human and sheep erythrocytes with values of $4.5 \mu \mathrm{g} / \mathrm{ml}$ for sheep blood cells, and $3.6 \mu \mathrm{g} / \mathrm{ml}$ for human red blood cells (data not shown). Surprisingly, the in vitro processed Cyt1 Ab1 toxin with gut extract, trypsin and chymotrypsin was more hemolytic to sheep erythrocytes than the untreated toxin form (Table II). This result indicates a possible role of the in vitro activation in potentiating the hemolytic activity of the toxin, as reported by Gill et al. (1987) and Al-yahyaee and Ellar (1995).
The N-terminal sequence analysis of the Cyt1Ab1 toxin processed by different proteases showed that the cutting sites in all treatments were very similar (Table III). C. quinquefasciatus gut extract cut at $\mathrm{Ile}^{31}-\mathrm{Asp}^{32}$, while Al-yahyaee and Ellar (1995) reported a cutting site between $\mathrm{Arg}^{30}$ $\mathrm{Val}^{31}$ for the Cyt1Aa1 toxin treated with Culex sp. gut extract. For the Cyt1Ab1 toxin, trypsin and chymotrypsin cutting sites were identified between $\mathrm{Leu}^{29}-\mathrm{Arg}^{30}$ and $\mathrm{Arg}^{30}{ }^{30 y s^{31}}$ respectively (Table III). Despite the almost 100\% homology between the Cyt1Aa1 and Cyt1Ab1 toxins in the first 40 aminoacids of the N-terminal region, data from $\mathrm{Al}-$ yahyaee and Ellar (1995) indicates a shift of several aminoacids when Cyt1Aa1 toxin was treated with trypsin and chymotrypsin (cutting sites $\mathrm{Val}^{26}$ and Lys ${ }^{18}$ respectively).

The role of solubilization and proteolysis of the Cyt1Ab1 toxin in hemolytic activity against sheep erythrocytes was demonstrated, although the proteolytically cleaved Cyt1Ab1 toxin was not toxic against third instar $C$. quinquefasciatus larvae, the role of this processing in toxicity can not be excluded.

\section{REFERENCES}

Al-yahyaee SAS, Ellar DJ 1995. Maximal toxicity of cloned CytA $\delta$-endotoxin from Bacillus thuringiensis subsp israelensis requires proteolytic processing from both the N- and C-termini. Microbiology 141: 3141-3148.

Aronson AI, Beckman W, Dunn P 1986. Bacillus thuringiensis and related insect pathogens. Microbiol Rev 50: 1-24.

Carroll J, Ellar DJ 1989. Proteolytic processing of a coleopteran-specific d-endotoxin produced by Bacillus thuringiensis var. tenebrionis. Biochem J 261: 99-105.

Chang C, Yu YM, Dai SM, Law SK, Gill SS 1993. Highlevel cryIVD and cytA gene expression in Bacillus thuringiensis does not require the 20-kilodalton protein, and the coexpressed gene products are synergistic in their toxicity to mosquitoes. Appl Environ Microbiol 59: 815-821.

Chilcott CN, Ellar DJ 1988. Comparative study of $\mathrm{Ba}$ cillus thuringiensis var. israelensis crystal proteins in vivo and in vitro. J Gen Microbiol 134: 25512558.

Crickmore N, Bone EJ, Willians JA, Ellar DJ 1995. Contribution of the individual components of the $\delta$ endotoxin crystal to the mosquitocidal activity of Bacillus thuringiensis subsp israelensis. FEMS Microbiol Lett 131: 249-254.

Crickmore N, Zeigler DR, Feitelson J, Schnepf E, Van Rie J, Lereclus D, Baum J, Dean DH 1998. Revision of the literature for the Bacillus thuringiensis pesticidal crystal proteins. Microbiol Mol Biol Rev 62: 807-813.

Dadd RH 1975. Alkalinity within the midgut of mosquito larvae with alkaline-active digestive enzimes. 
J Insect Physiol 21: 1847-1853.

Dai SM, Gill SS 1993. In vitro and in vivo proteolysis of the Bacillus thuringiensis subsp. israelensis CryIVD protein by Culex quinquefasciatus larval midgut proteases. Insect Biochem Molec Biol 23: 273-283.

Fast PG, Milne R 1979. Bacillus thuringiensis parasporal toxin: dissolution of crystals with retention of toxicity. J Invertebr Pathol 34: 319.

Federici BA, Bauer LS 1998. Cyt1Aa protein of Bacillus thuringiensis is toxic to the cottonwood leaf beetle, Chrysomela scripta, and suppresses high levels of resistance to Cry3Aa. Appl Environ Microbiol 64: 4368-4371.

Garczynski SF, Crim JW, Adang MJ 1991. Identification of putative insect brush border membrane-binding molecules specific to Bacillus thuringiensis $\delta$ endotoxin by protein blot analysis. Appl Environ Microbiol 57: 2816-2820.

Gill SS, Singh GJP, Hornung JM 1987. Cell membrane interaction of Bacillus thuringiensis subsp. israelensis cytolytic toxins. Infect Immun 55: 13001308.

Höfte H, Whiteley HR 1989. Insecticidal crystal proteins of Bacillus thuringiensis. Microbiol Rev 53: 242-255.

Knowles BH, White PJ, Nicholls CN, Ellar DJ 1992. A broad spectrum cytolytic toxin from Bacillus thuringiensis subsp kyushuensis. Proc Roy Soc Lond Ser B 248: 1-7.

Koni PA, Ellar DJ 1994. Biochemical characterization of Bacillus thuringiensis cytolytic $\delta$-endotoxins. Microbiology 140: 1869-1880.

Kunz P 1978. Resolution and properties of the proteinases in the larvae of the mosquito, Aedes aegypti. Insect Biochem 8: 43-51.

Li J, Koni PA, Ellar DJ 1996. Structure of the mosquitocidal $\delta$-endotoxin CytB from Bacillus thuringiensis subsp kyushuensis and implications for membrane pore formation. J Mol Biol 257: 129-152.

Mozdzanowski J, Speicher DW 1992. Microsequence analysis of electroblotted proteins. I. Comparison of electroblotting recoveries using different types of PVDF membranes. Anal Biochem 207: 11-18.

Ogiwara K, Indrasith LS, Asano S, Hori H 1992. Processing of $\delta$-endotoxin from Bacillus thuringiensis subsp. kurstaki HD-1 and HD-73 by gut juices of various insect larvae. J Invertebr Pathol 60: 121126.

Orduz S, Diaz T, Restrepo N, Patiño MM, Tamayo MC 1996. Biochemical, immunological and toxicological characteristics of the crystal proteins of Bacillus thuringiensis subsp medellin. Mem Inst Oswaldo Cruz 91: 231-237.

Orduz S, Diaz T, Thiéry I, Charles JF, Rojas W 1994. Crystal proteins from Bacillus thuringiensis serovar medellin. Appl Microbiol Biotechnol 40: 794-799.

Orduz S, Realpe M, Arango R, Murillo LA, Delécluse A 1998. Sequence of the $c r y 11 B b$ gene from Bacillus thuringiensis subsp. medellin and toxicity analy- sis of its encoded protein. Biochem Biophys Acta $1388: 267-272$

Orduz S, Rojas W, Correa MM, Montoya AE, de Barjac H 1992. A new serotype Bacillus thuringiensis from Colombia toxic to mosquito larvae. J Invertebr Pathol 59: 99-103.

Pfannenstiel MA, Cray WC Jr, Couche GA, Nickerson KW 1990. Toxicity of protease-resistant domains from the $\delta$-endotoxin of Bacillus thuringiensis subsp. israelensis in Culex quinquefasciatus and Aedes aegypti bioassays. Appl Environ Microbiol 56: $162-$ 166.

Raymond M 1995. Presentation d'un programme d'analyse log-probit pour micro-ordinnateur. $\mathrm{Cah}$ ORSTOM Ser Ent Med Parasitol 22: 117-121.

Restrepo N, Gutierrez D, Patiño MM, Thiéry I, Delécluse A, Orduz S 1997. Cloning, expression and toxicity of a mosquitocidal toxin gene of Bacillus thuringiensis subsp. medellin. Mem Inst Oswaldo Cruz, 92: 257-262.

Sambrook J, Fritsch EF, Maniatis T 1989. Molecular Cloning. A Laboratory Manual, Volumes 1, 2, and 3, 2nd ed., Cold Spring Harbor Laboratory Press, New York.

Seebacher T, Bade EG 1996. Quick and easy molecular weight determination with Macintosh computer and public domain image analysis software. Electrophoresis 17: 1573-1774.

Schnell DJ, Pfannenstiel MA, Nickerson KW 1984. Bioassay of solubilized Bacillus thuringiensis var. israelensis crystals by attachment to latex beads. Science 223: 1191-1193.

Schnepf E, Crickmore N, Van Rie J, Lereclus D, Baim J, Feitelson J, Zeigler D, Dean DH 1998. Bacillus thuringiensis and its pesticidal crystal proteins. Microbiol Mol Biol Rev 62: 775-806.

Thiéry I, Delécluse A, Tamayo MC, Orduz S 1997. Identification of a gene for Cyt1A-like hemolysin from Bacillus thuringiensis subsp. medellin and expression in a crystal-negative $B$. thuringiensis strain. Appl Environ Microbiol 63: 468-473.

Thiéry I, Hamon S, Deléclusse A, Orduz S 1998. The introduction into Bacillus sphaericus of the Bacillus thuringiensis subsp. medellin cytlAbl gene results in higher susceptibility of resistant mosquito larva populations to B. sphaericus. Appl Environ Microbiol 64: 3910-3916.

Tojo A, Aizawa K 1983. Dissolution and degradation of Bacillus thuringiensis delta-endotoxin by gut juice protease of the silkworm Bombix mori. Appl Environ Microbiol 45: 576-580.

van Frankenhuyzen K, Gringorten JL, Gauthier D, Milne RE, Masson L, Peferoen M 1993. Toxicity of activated CryI proteins from Bacillus thuringiensis to six forest lepidoptera and Bombyx mori. J Invertebr Pathol 62: 295-301.

Yang YJ, Davies DM 1971. Digestive enzymes in the excreta of Aedes aegypti larvae. J Insect Physiol 17: 2119-2123. 